\title{
How Exposure to Ultrafine and Fine Particles of Car Smoke Can Alter Erythrocyte Forms of Male Mice
}

\author{
Arinto Y.P. Wardoyo ${ }^{1 *}$, Unggul P. Juswono ${ }^{2}$, Johan A. E. Noor ${ }^{2}$ \\ ${ }^{1}$ Laboratory of Air Quality and Astro Imaging, Department of Physics, University of Brawijaya, \\ Malang, East Java, Indonesia \\ ${ }^{2}$ Laboratory of Experimental Physics, Department of Physics, University of Brawijaya, \\ Malang, East Java, Indonesia
}

Received: 3 July 2018

Accepted: 7 August 2018

\begin{abstract}
Exposure to particulate matter (PM) has been identified as being responsible for affecting human health. Their impacts on erythrocytes are still unclear, especially PMs emitted from motor vehicles. This study investigated the correlation between exposures to inflammatory agents of particulate matters (in terms of ultrafine particles, or $\mathrm{PM}_{0.1}$, and fine particles, or $\mathrm{PM}_{2.5}$ ) contained in gasoline engine car exhaust emissions and the deformation of mice erythrocytes. We used 65 male mice as experimental animals. The mice were exposed to the filtered and unfiltered $\mathrm{PM}_{0.1}-\mathrm{PM}_{2.5}$ for 100 seconds for as long as 8 consecutive days. The mice from each group were sacrificed on the $8^{\text {th }}$ day of blood preparation. All blood samples were observed using a digital microscope (400x magnification) to calculate the amount of normal and deformed erythrocytes. The results showed that the increasing amount of $\mathrm{PM}_{0.1}$ and $\mathrm{PM}_{2.5}$ in the car smoke that was exposed to the mice caused the increasing of the erythrocyte deformation percentages. The erythrocyte deformation percentage was found linearly to the particle concentration.
\end{abstract}

Keywords: car smoke exposure; ultrafine particles; fine particles; mice erythrocyte

\section{Introduction}

Air pollutants have been identified in terms of gases and particulate matter, which consists of small solid particles and liquid droplets. The diameter of particulate matter varies from several $\mu \mathrm{m}$ to more than $10 \mu \mathrm{m}$. Fine particles or $\mathrm{PM}_{2.5}$ are particulate matters having a diameter less than $2.5 \mu \mathrm{m}$, while ultrafine

*e-mail: a.wardoyo@ub.ac.id particles or $\mathrm{PM}_{0.1}$ have a diameter less than $0.1 \mu \mathrm{m}$. The constituent, concentration and size distribution depends on the source. Generally, particulate matter is derived from anthropogenic and natural sources. As an anthropogenic source, smoking activity generates particulate matter having a diameter between $0.02 \mu \mathrm{m}$ to $1 \mu \mathrm{m}$. The measured concentrations are varied from 41,800 to 115,000 particles $/ \mathrm{cm}^{3}$ [1]. Numerous recent studies have investigated the other sources of PM related to size distribution and the constituent. As a key point, the primary PM source is human activity, including biomass burning [2], road traffic sector [3], daily 
cooking [4], printing [5] and many other activities, while the secondary source comes from non-anthropogenic sources such as volcanic eruption [6] and forest fires [7]. The previous airborne field measurements of biomass particles in the Australia's Northern Territory reported that most of the early dry season particles with a count median diameter of $83 \pm 13 \mathrm{~nm}$ came from fresh smoke [8].

The effect of different particulate matters on health has been studied previously, such as diesel exhaust particles [9], ultrafine carbon particles [10] and nanosilver [11]. $\mathrm{PM}_{0.1}$ and $\mathrm{PM}_{2.5}$ exposures were associated with the risk of mortality. $\mathrm{PM}_{2.5}$ alters a ventricular repolarization and may increase a myocardial vulnerability to arrhythmia [12]. $\mathrm{PM}_{01}$ is deposited deeply into the human body compared to bigger particles. They cause gene mutations and induce inflammation [11]. Inhaled $\mathrm{PM}_{0.1}$ is related to the respiratory system in terms of all major lung tissue compartments and cells, and may trigger a higher toxic potential [13]. Although $\mathrm{PM}_{0.1}$ and $\mathrm{PM}_{2.5}$ impacts on the blood and blood pressure have been studied [14-16], we still have only limited information on blood cell deformation.

Cell deformation is an alteration of cells induced by the inflammatory response due to an inflammatory agent. As is well known, erythrocytes play an important role in oxygen transport [17]. Any deformation in erythrocytes indicates a response of the deforming force. The deformation may influence blood viscosity [18], reactive oxygen species production [19] and hemorheological alterations [20]. Any alteration due to erythrocytes deformation or the morphological changes become a marker of abnormalities, such as sickle cell disease [21], iron deficiency anemia, and thalassemia [22]. Due to the very important role of erythrocytes, it is necessary to investigate the correlation between the inflammatory agent and erythrocytes morphological changes (also known as cell deformation).

In spite of the fact that the deformation level of erythrocytes investigation is very important for blood analysis of the human body, studies dealing with the deformation model of erythrocytes during normal and abnormal conditions are rare. A way to define the level of erythrocyte deformation due to particulate interaction and the explanation is limited. Recent studies still only focus on erythrocyte morphology without any correlation with particulate matter as the inflammatory agent. The conducted study is supposed to carry on the latest information related to the standpoint of pathology. There is a lack of literature data on the physical changes of erythrocytes, including the histological, conventional and quantitative methods used to determine the erythrocyte deformation characteristic in vivo or in vitro. In order to get a better understanding of erythrocyte deformation due to an inflammatory agent in terms of particulate matters with a different size that has been unknown well at the moment, we studied an in vivo model to investigate the relationship between erythrocyte deformation and exposure to $\mathrm{PM}_{0.1}$ and $\mathrm{PM}_{2.5}$ contained in the car exhaust emission. Moreover, the study may establish the possible alteration of exposure to $\mathrm{PM}_{0.1}$ and $\mathrm{PM}_{2.5}$ emitted by gasoline car engine on mice erythrocytes and strengthen the knowledge of the impact of particulate matters with different size distribution.

\section{Materials and Methods}

\section{Generation of Particulate Matters}

$\mathrm{PM}_{0.1}$ and $\mathrm{PM}_{2.5}$ were generated from four standard gasoline car exhaust emissions (M1, M2, M3 and M4) under a controlled steady-state condition with $1000 \mathrm{rpm}$ engine speed. The exhaust emission of the sample car was sucked by a pump at a rate of $2.03 \mathrm{~m} / \mathrm{s}$ and introduced to a $0.3 \times 0.2 \times 0.2 \mathrm{~m}^{3}$ exposure chamber for 60 seconds. The generated exhaust emission was filtered using a particulate matter cyclone (constant debit: $33.05 \mathrm{~cm}^{3} / \mathrm{s}$ ). The $\mathrm{PM}_{0.1}$ (diameter 0.02-0.10 $\mu \mathrm{m}$ ) and $\mathrm{PM}_{2.5}$ (diameter $0.10-2.50 \mu \mathrm{m}$ ) concentrations in the filtered exhaust emission were measured using a P-Trak ultrafine particle counter (TSI, model 8525) and a digital dust monitor (Kanomax, model 3443).

\section{Animal Treatment}

Male 11-week-old Wistar mice $(\mathrm{n}=65)$ were housed in acrylic cages after three days of acclimation. They were kept at controlled light (12:12 dark-light cycle) and temperature $\left(26-29^{\circ} \mathrm{C}\right)$, with $57.8-58.8 \%$ humidity. All mice were treated humanely and provided with water and foods ad libitum. All the procedures were approved by the Animal Care and Use Committee of Brawijaya University Malang, Indonesia (Ethical Clearance No: 541-KEP-UB). The mice were arranged into Control (-) that the unexposed mice, Controls (+) that the mice were exposed to the unfiltered emission, the $\mathrm{PM}_{01}$ groups which were the mice group that was exposed by the $\mathrm{PM}_{01}$ emission with the car sample of M1-M4, and the $\mathrm{PM}_{2.5}$ groups which were the mice group that was exposed by $\mathrm{PM}_{0.1}$ emissions with the car sample of M1-M4 (Table 1). After exposure treatment, all mice were sacrificed. The blood drops were placed onto object glasses (1.0-1.2 mm of thickness) and fixed

Table 1. Experimental groups of mice.

\begin{tabular}{|c|c|c|}
\hline Group & Particulate Matter & Mice \\
\hline Control (-) & - & 5 \\
\hline Control (+) & Unfiltered exhaust emission & 20 \\
\hline $\mathrm{PM}_{0.1}$ & Filtered $\mathrm{PM}_{0.1}$ & 20 \\
\hline $\mathrm{PM}_{2.5}$ & Filtered $\mathrm{PM}_{2.5}$ & 20 \\
\hline
\end{tabular}


with methanol solutions $(70 \%)$. When they came dried ( \pm 5 minutes) they were colored using Giemsa and buffer pro Giemsa solution (1:3), then rinsed using water. Each slide was imaged under a computer microscope (400x magnification).

\section{Histological Examination}

The digital images from the observed slides were used to determine the number fraction of the major morphological changes of erythrocytes by a manual counting of the cells. The total of deformed (abnormal erythrocytes) and normal erythrocytes was averaged from ten fields of view for each animal and then averaged from five animals. Cell deformation $(C D)$ was calculated using the equation:

$$
\begin{gathered}
C D=\left[\sum\right. \text { Abnormal erythrocytes } \\
\left./ \sum \text { Erythrocytes }\right] \times 100 \%
\end{gathered}
$$

\section{Statistical Analysis}

Data were represented as the arithmetic means \pm standard deviation. Differences between groups were evaluated using Student's $t$-test. A linear regression analysis was applied to assess and to evaluate the correlation between the exposure to PMs concentration and erythrocyte deformation using Microsoft Excel 2016 and SigmaPlot 14.0. $R^{2}>0.80$ was considered highly correlated, while $p \leq 0.05$ was considered to show statistical significance.

\section{Results and Discussion}

$$
\mathrm{PM}_{0.1} \text { and } \mathrm{PM}_{2.5} \text { Exposures }
$$

In order to determine the dose concentrations of $\mathrm{PM}_{0.1}$ and $\mathrm{PM}_{2.5}$ to which the mice were exposed, we conducted the $\mathrm{PM}_{0.1}$ and $\mathrm{PM}_{2.5}$ concentration measurements with and without the filtering systems. The measurements were repeated three times in a completely closed exposure chamber for all car samples. As a result, Fig. 1 shows the example graph of the measured particle concentrations for sample M4.

As seen in Fig. 1(a-b), the filtered and unfiltered $\mathrm{PM}_{0.1}$ concentrations decrease logarithmically. The results of the three measurements show a similar trend. This indicates the measurement consistency, and there is no significant difference between the three repeated measurements $(p>0.05)$. M4 generates 427,800 particles $/ \mathrm{cm}^{3}$ and $2.04 \mathrm{mg} / \mathrm{m}^{3}$ of filtered $\mathrm{PM}_{0.1}$ and $\mathrm{PM}_{2.5}$ concentrations. A similar consistency

b)
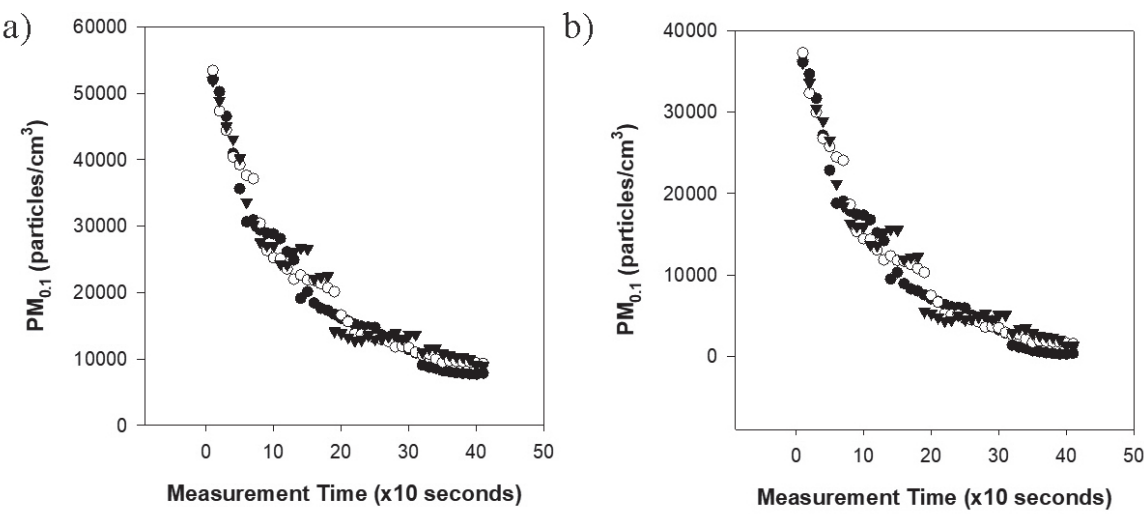

c)

d)

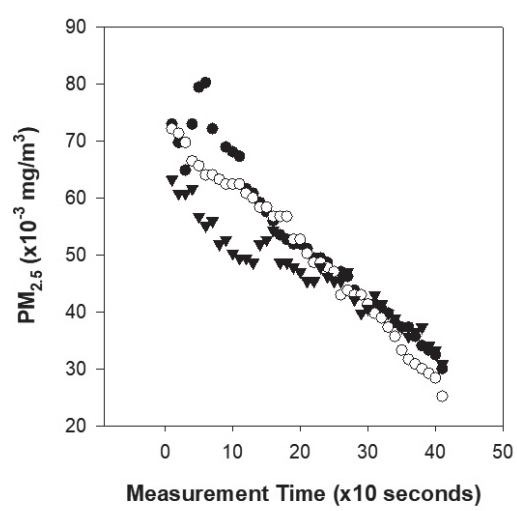

Fig. 1. Measured particle concentrations from M4 sample: a) Unfiltered $\mathrm{PM}_{0.1}$, b) $\mathrm{PM}_{0.1}$, c) Unfiltered $\mathrm{PM}_{2.5}$ and d) $\mathrm{PM}_{2.5}$. 
Table 2. Concentrations of $\mathrm{PM}_{0.1}$ and $\mathrm{PM}_{2.5}$ exposed to mice for 8 consecutive days.

\begin{tabular}{|c|c|c|c|c|}
\hline Exposed Particulate Matters & M1 & M2 & M3 & M4 \\
\hline $\mathrm{PM}_{0.1}\left(\mathrm{x} 10^{6} \mathrm{pt} / \mathrm{cm}^{3}\right)$ & $1.01 \pm 0.02$ & $2.31 \pm 0.25$ & $2.64 \pm 0.11$ & $3.42 \pm 0.07$ \\
\hline $\mathrm{PM}_{2.5}\left(\mathrm{mg} / \mathrm{m}^{3}\right)$ & $0.51 \pm 0.02$ & $9.03 \pm 0.86$ & $14.22 \pm 0.92$ & $16.32 \pm 0.54$ \\
\hline Unfiltered $\mathrm{PM}_{0.1}\left(\mathrm{x} 10^{6} \mathrm{pt} / \mathrm{cm}^{3}\right)$ & $3.50 \pm 0.03$ & $6.32 \pm 0.30$ & $6.49 \pm 0.13$ & $6.65 \pm 0.09$ \\
\hline Unfiltered $\mathrm{PM}_{2.5}\left(\mathrm{mg} / \mathrm{m}^{3}\right)$ & $0.63 \pm 0.03$ & $11.74 \pm 0.86$ & $17.56 \pm 1.13$ & $20.15 \pm 0.66$ \\
\hline
\end{tabular}

is also found in the filtered and unfiltered $\mathrm{PM}_{2.5}$ concentrations (Fig. 1c-d), which decrease linearly. According to Fig. 1, the mean concentrations of unfiltered $\mathrm{PM}_{0.1}$ and $\mathrm{PM}_{2.5}$ emitted by $\mathrm{M} 4$ (engine capacity of $1,500 \mathrm{~cm}^{3}$ ) for a single exposure are 831,800 particles $/ \mathrm{cm}^{3}$ and $2.52 \mathrm{mg} / \mathrm{m}^{3}$, respectively. These concentrations are 20,100 particles $/ \mathrm{cm}^{3}$ and $0.32 \mathrm{mg} / \mathrm{m}^{3}$ higher than the concentrations emitted by M3 (engine capacity $=1400 \mathrm{~cm}^{3}$ ). The concentrations are 404,000 particles $/ \mathrm{cm}^{3}$ and $0.48 \mathrm{mg} / \mathrm{m}^{3}$ higher than the filtered $\mathrm{PM}_{0.1}$ and $\mathrm{PM}_{2.5}$ concentrations of M4. The obtained results show that a higher engine capacity generates more PM concentrations. The lowest filtered $\mathrm{PM}_{0.1}$ and $\mathrm{PM}_{2.5}$ concentrations $\left(125,600\right.$ particles $/ \mathrm{cm}^{3}$ and $0.06 \mathrm{mg} / \mathrm{m}^{3}$, respectively) are derived from M1 (engine capacity $=1000 \mathrm{~cm}^{3}$ ). The unfiltered $\mathrm{PM}_{0.1}$ and $\mathrm{PM}_{2.5}$ concentrations of $\mathrm{M} 1$ are 439,000 particles $/ \mathrm{cm}^{3}$ and $0.08 \mathrm{mg} / \mathrm{m}^{3}$, respectively. M2 (engine capacity $=1200 \mathrm{~cm}^{3}$ ) generates 291,100 and 789,400 particles $/ \mathrm{cm}^{3}$ for filtered and unfiltered $\mathrm{PM}_{0.1}$ concentrations, and 1.13 and $1.47 \mathrm{mg} / \mathrm{m}^{3}$ for filtered and unfiltered $\mathrm{PM}_{2.5}$ concentrations.
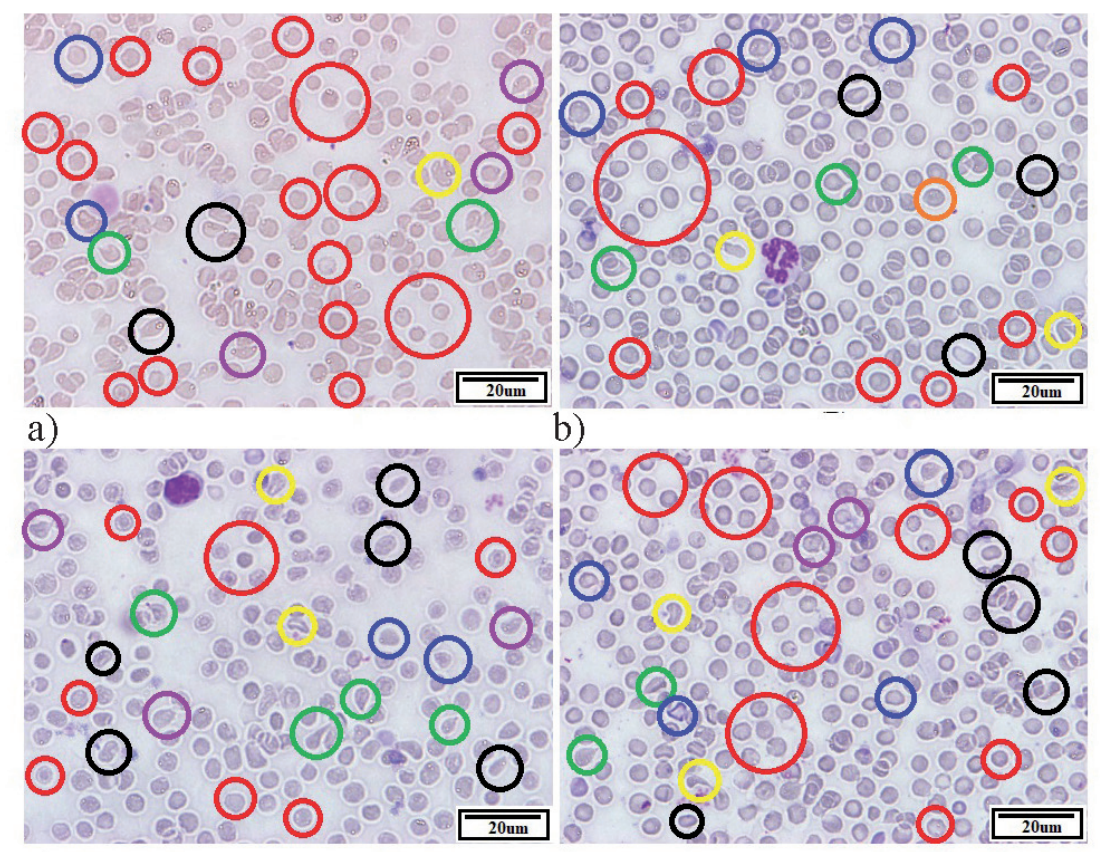

b)

c)

d)

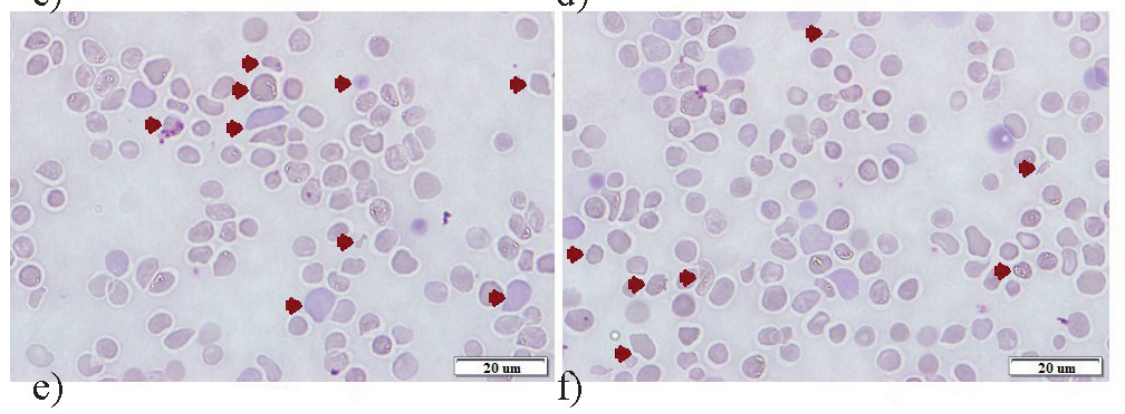

Fig. 2. Poikilocytosis (abnormally shaped erythrocytes) for the groups of: a) control (-), b) $\mathrm{PM}_{0.1} \mathrm{M} 4$, c) $\mathrm{PM}_{2.5} \mathrm{M} 4$ and d) CTM4. The observed erythrocytes: normal (red circles); schistocyte (yellow circles), stomatocyte (orange circles), dacrocyte (green circles), helmetshaped (blue circles), saddle-shaped (purple circles), and ovalocyte (black circles). (e-f). Deformed erythrocytes with the tendency of cell death (necrosis), cell adaptation (atrophy-hypertrophy-like cells, macro-microcytes), and cell damage, indicated by the brown arrows. All figure scale bars: $20 \mu \mathrm{m}$. 
The total concentration of PM is determined by multiplying the total concentration in the single exposure to the exposure days ( 8 days). All data are presented in Table 2. The lowest concentrations are obtained from M1. Meanwhile, the highest concentrations are found in the exhaust emission from M4. The sample engine capacity determines the particulate matter concentration. The car with the small engine produces relatively less particulate matters rather than a bigger engine.

\section{Deformation Percentages}

Fig. 2 shows the histological images of the blood smears taken from the $1^{\text {st }}$ group M1. Based on the images, we identified the normal (healthy) and abnormal erythrocytes according to their shapes (physical damages). The deformation changes of the erythrocytes were compared from the normal shapes.

According to Fig. 2, a normal erythrocyte (red circle) has a biconcave shape. Compared to Fig. 2(b-f) (exposed mice), the normal erythrocytes are significantly found in the Control (-) group. By contrast, the number of abnormal erythrocytes increase significantly in the exposed mice. The abnormal ones found here are schistocyte (sickle-shaped), stomatocyte, dacrocyte, helmet-shaped, saddleshaped and ovalocyte. As indicated in the figure, when erythrocytes deform into different shapes, they have a different physical look. The abnormal erythrocytes are found in the shapes schistocyte (yellow circles), stomatocyte (orange circles), dacrocyte (green circles), helmet-shaped (blue circles), saddle-shaped (purple circles) and ovalocyte (black circles). Schistocyte and ovalocyte are the most abnormalities found in this study. All of this poikilocytosis is typically due to the deformation of structural membrane components. A schistocyte is identified as an irregularly shaped cell having two pointed ends (sickle-shaped). The two pointed ends are different from the saddle-shaped and helmet-shaped cells. A dacrocyte (teardrop-shaped cell) is determined as an erythrocyte that looks like a teardrop. The three deformation types dominate the abnormality level of the observed erythrocytes. As depicted in Fig. 2, a stomatocyte is shown as an erythrocyte (shaped like a coffee bean), while a saddleshaped cell is similar to a horse saddle. An ovalocyte (elliptocyte) is indicated as an elongated oval cell.

Fig. 3 depicts the erythrocyte deformation percentages as a function of Control (-) group, Control $(+)$ groups and filtered $\mathrm{PM}_{0.1}-\mathrm{PM}_{2.5}$ groups from $\mathrm{M} 1$, M2, M3 and M4. For sample M1, mice exposure with the filtered $\mathrm{PM}_{0.1}$ concentration of $\left(1.01 \times 10^{6}\right)$ particles/ $\mathrm{cm}^{3}$ causes the deformation of $27 \%$, and a filtered $\mathrm{PM}_{2.5}$ concentration of $\left(0.51 \times 10^{-6}\right) \mathrm{mg} / \mathrm{cm}^{3}$ results in the deformation of $21 \%$. The number of normal erythrocytes is 298 and 327 cells, respectively. Increasing the dose concentration of $\mathrm{PM}_{0.1}$ and $\mathrm{PM}_{2.5}$ (M2) to become $\left(2.31 \times 10^{6}\right)$ particles $/ \mathrm{cm}^{3}$ and $\left(9.03 \times 10^{-6}\right) \mathrm{mg} / \mathrm{cm}^{3}$ affects the erythrocyte deformation to become larger to $29 \%$

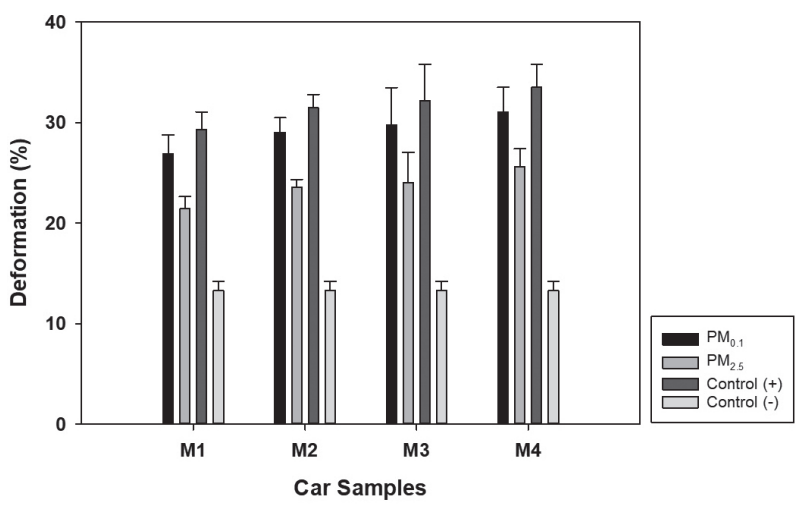

Fig. 3. Differential deformation percentages in mice erythrocytes obtained from the exposed groups Control $(+)$, $\mathrm{PM}_{0.1}, \mathrm{PM}_{2.5}(\mathrm{n}=5$ per group) vs. the group of Control (-) $(\mathrm{n}=5)$, means $\pm \mathrm{SD}(p<0.05)$.

for $\mathrm{PM}_{0.1} \mathrm{M} 2$ and $24 \%$ for $\mathrm{PM}_{2.5} \mathrm{M} 2$, where the number of abnormal erythrocytes increases to $87\left(\mathrm{PM}_{0.1}\right)$ and $71\left(\mathrm{PM}_{2.5}\right)$ cells. The normal erythrocytes from $\mathrm{PM}_{0.1} \mathrm{M} 2$ and $\mathrm{PM}_{2.5} \mathrm{M} 2$ groups are 213 and 230 cells, respectively. There are significant differences between exposed mice in $\mathrm{M} 2\left(\mathrm{PM}_{0.1} \mathrm{M} 2\right.$ and $\mathrm{PM}_{2.5} \mathrm{M} 2$ groups $)$ and Control $(-)$ mice $(p<0.05)$. Similarly, the differences of the deformation percentages are significant $(p<0.05)$ between exposed mice M3 $\left(\mathrm{PM}_{0.1} \mathrm{M} 3\right.$ and $\mathrm{PM}_{2.5} \mathrm{M} 3$ groups) and Control (-) mice. We increased the dose exposure concentration of filtered $\mathrm{PM}_{0.1}$ and $\mathrm{PM}_{2.5}$ to become $\left(2.64 \times 10^{6}\right)$ particles $/ \mathrm{cm}^{3}$ and $\left(14.22 \times 10^{-6}\right) \mathrm{mg} / \mathrm{m}^{3}$ (M3) caused the erythrocyte deformation to become $30 \%$ for $\mathrm{PM}_{01}$ and $24 \%$ for $\mathrm{PM}_{2.5}$. The number of abnormal erythrocytes was also increased to $81\left(\mathrm{PM}_{0.1} \mathrm{M} 3\right)$ and $66\left(\mathrm{PM}_{2.5} \mathrm{M} 3\right)$ cells. The trend of the increasing of the erythrocyte damage due to adding the dose concentrations are found similarly for all car samples, including the results obtained in M4. The groups of $\mathrm{PM}_{0.1} \mathrm{M} 4, \mathrm{PM}_{2.5} \mathrm{M} 4$ and Control (+) M4 cause $31 \%, 26 \%$ and $34 \%$ of the erythrocyte deformation percentages, respectively. Based on all results from M1-M4, the deformation percentages are up to $8 \%$ larger than the deformation percentages in the Control (-) group (13\%). The complete results show that more PM concentration caused more deformation in the mice erythrocytes $(p<0.05)$.

In order to get a better understanding about the correlation between total concentrations of both filtered and unfiltered $\mathrm{PM}_{0.1}-\mathrm{PM}_{2.5}$ in the smoke and the deformation percentages of mice erythrocytes, we present the graphs shown in Fig. 4. The deformation percentages of each treatment group are alleviated with the deformation percentage obtained from the Control (-) group. The relationship between erythrocyte deformation and total particulate concentration is approached by linear regression with the $R^{2}$ coefficients $>0.80$ (Fig. 4). This shows that the $\mathrm{PM}_{0.1}$ and $\mathrm{PM}_{2.5}$ concentrations in the exhaust emission significantly influence erythrocyte deformation. Moreover, 

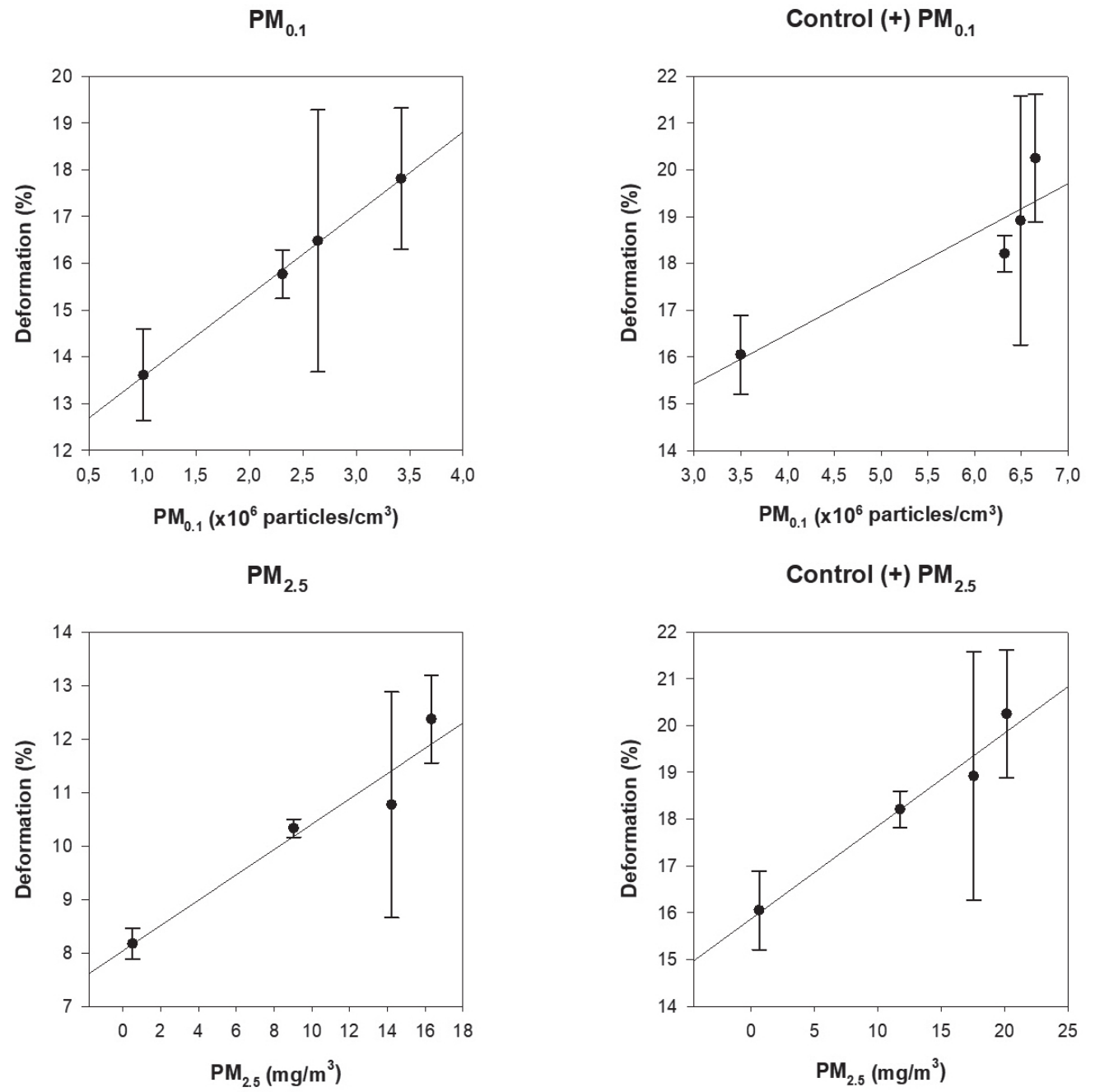

Fig. 4.Correlation between the total concentrations of filtered-unfiltered $\mathrm{PM}_{0.1}-\mathrm{PM}_{2.5}$ vs. the deformation percentages in M1-M4. Results are interpreted as the means $\pm \mathrm{SD}$ (statistically correlated $R^{2}>0.80$ ).

erythrocyte cell deformation is related to the engine capacity of the car samples. Exposure of the mice to the exhaust emissions emitted from the different engine capacities results in a variation of erythrocyte deformation. Larger engine capacity producing the exhaust emission with a larger concentration of $\mathrm{PM}_{01}$ and $\mathrm{PM}_{2.5}$ causes more deformation of the erythrocyte. The measurements of the particulate matter concentrations emitted from motor vehicles conducted in the laboratory and on a road site in previous studies confirm the results [3, 23-25]. When we exposed the mice to the exhaust emission with varied concentrations, we found that erythrocyte deformation was in a different percentage, which was proportional to the dose concentration. Sample M1, which is a car with an engine capacity of $1000 \mathrm{~cm}^{3}$, generates the lowest erythrocyte deformation among other car samples.

The exposure to $\mathrm{PM}_{0.1}$ and $\mathrm{PM}_{2.5}$ contained in the car smoke alters the mice erythrocyte with typical characteristics. Our findings indeed show that there is a significant correlation between the $\mathrm{PM}_{0.1}$ and $\mathrm{PM}_{2.5}$ concentrations and the mice erythrocyte deformation or physical damage. The results show that more dose of pathology agents $\left(\mathrm{PM}_{01}\right.$ and $\left.\mathrm{PM}_{25}\right)$ results in more erythrocyte physical damage. With a similar concentration of smoke, we found that the $\mathrm{PM}_{0.1}$ caused more erythrocyte deformation than $\mathrm{PM}_{2.5}$. Previous work from our lab and others has demonstrated that greater cell deformability is caused by $\mathrm{PM}_{0.1}$ rather than large ones [26]. In a mouse model, exposure to $\mathrm{PM}_{0.1}$ generated from motorcycle exhaust emissions altered the morphology of erythrocytes, including changes in normal and abnormal erythrocyte levels [23]. Thus, erythrocyte deformation can be used as biophysical parameters to determine the pathology impacts of particulate matter exposures in this study.

In order to investigate the pathological effects of particulate matters in mice erythrocytes, we need to predict the particulate matter mechanism to the cells starting from the upper respiratory tract to the lower respiratory tract. For the first step, the particulate matter $\mathrm{PM}_{0.1}$ and $\mathrm{PM}_{2.5}$ become the pathology agents at different toxicity levels. In this state, the particulate matter deposition into the organ is needed to be 
investigated. The respiratory tracts may contribute to particle deposition with different values [27, 28] depending on the pulmonary response to the inhalation that is correlated with lung capacity (in accordance with the tidal volume of mice). In the second step, oxidative stress due to particulate matter deposition needs to be investigated [29]. When the submicron particles are inhaled, whether $\mathrm{PM}_{0.1}$ and $\mathrm{PM}_{2.5}$, they may directly interact with the respiratory system and induce oxidative stress inflammation. Thus, the inflammation and oxidative stress may trigger other possible responses, such as pro-oxidative and pro-inflammatory mediators, releasing as systemic chain reaction [30,31]. In the blood system, particulate matters possibly unite with the mice erythrocytes and disturb the transport mechanism of the cation and many other proteins, and of course cause inflammation. The evidence suggests that oxidation of membrane lipids and proteins are linked to the increase of oxidative stress and inflammation and are able to damage erythrocytes [32]. As confirmed in the recent study, the inflammatory mediators can be found as cytokine IL-8 as a signal that attracts the neutrophils at the site of inflammation [33]. On the other hand, inflammation becomes a non-specific body immune response that indicates the body reaction to allergic reaction [21]. In mice model, short and long-term exposure to nickel hydroxide nanoparticles induced histological changes in lung tissue as responses to inflammation [34]. Significant pulmonary inflammatory was also observed in the response to ultrafine particle and submicron fine particle exposure, as indicated by the changes of bronchoalveolar lavage fluid protein, neutrophils, eosinophils and LDH levels in mice [35]. Similarly, the impact of these oxidative stress and inflammation conditions is interpreted as the physical cell damage that can be used to predict the potential influence of pathologic agents [29, 36]. In normal conditions, the erythrocytes are in the form of biconcave with smooth edges [37]. Erythrocytes have a lipid bilayer and many peripheral proteins. The disruption of the membrane leaflet due to particulate matters may cause physical cell damage. According to the results, cell damage is typically observed in the changes of the erythrocyte morphology. As reported in a recent study, cell deformation was used as the hematological examination in accordance with the pathological examination [17].

In accordance with the standpoint of pathology, particulate matter accumulation may induce histological changes, including cell death due to inflammatory agents and cell adaptation [38]. The histological examination results show the reduction in the diameter of the mice erythrocytes (Fig. 2) compared to the unexposed mice, which may also be influenced by the genetic instability caused by toxic agents (cell adaptation) [32]. In the digital images we also found enlarged erythrocytes. These atrophy-hypertrophy-like cells (cell adaptation) may represent cell adaptation due to any inflammatory agents (Fig. 2). For part of cell adaptation, erythrocyte may respond to the inflammatory agent by changing the morphology [32]. In an acute condition, cell deformation may also be related to cell death in term of necrosis, which can be identified by the disruption of cell membrane integrity [39]. It is associated with cell rigidity, membrane biochemical changes and cell shape [32]. This phenomenon has a high possibility to influence erythrocyte survival and increase cell rigidity, as investigated on the histological examination.

Previous studies measured the substances of particulate matters, such as polycyclic aromatic hydrocarbons and volatile organic compounds emitted by motor vehicle exhaust [40-42]. Polycyclic aromatic hydrocarbons as the kind of organic compounds, together with their derivatives, are well-known to be carcinogens for human health [43-45]. Polycyclic aromatic hydrocarbons may be contents of anthracene, phenanthrene, fluoranthene, benzo(a)pyrene, pyrene, naphthalene and many other forms [40, 46]. Motor vehicles also emit high volatile organic compound emissions as primary compounds as the products of both complete or incomplete combustion [47]. When these particulate matters are inhaled and deposited, the reaction with biomolecule cells may trigger reactive oxygen species, causing inflammation [21].

The reaction may happen in the erythrocytes, too. However, there is insufficient information and further evidence about this phenomena. In this study, we found erythrocyte anomalies such as teardrop-shaped cells, helmet-shaped cells, sickle-shaped cells, and elliptocytes in which the normal shape that is shown as a dominant typical biconcave form and smooth edge [17]. Most erythrocyte anomalies in the shape of teardrop-shaped cells and elliptocytes were observed when we exposed the mice to the filtered particulate smoke. According to a recent study, erythrocyte physical damages such as teardrop-shaped (dacrocyte) and sickle-shaped (drepanocyte, sickle cell and schistocyte cell) can be used to track disease progression due to inflammatory agents or toxic substances. A lysis of erythrocytes might be related for any diseases, such as sickle cell disease [21], iron deficiency anemia and thalassemia [22].

\section{Conclusions}

In conclusion, car exhaust emission exposures to mice affected erythrocyte deformation, which depended on the particulate matter concentration with significant linear correlation. Smaller particulate matter had a greater effect on erythrocytes.

\section{Acknowledgements}

All the authors are grateful to the Ministry of Research, Technology and Higher Education for providing funding for this research project (contract 
No. 033/SP2H/LT/DRPM/II/2016, 17 February 2016 and 137/SP2H/LT/DRPM/II/2016, 10 March 2016).

\section{Conflict of Interest}

The authors declare no conflict of interest.

\section{References}

1. WARDOYO A.Y.P., SANTJOJO D.J.D.H., RAHAYU T., SUBAGYO S. Influence of smoking rate on ultrafine particle emission of cigarette smoke. Journal of Biological Researches. 23, 90, 2018.

2. WARDOYO A.Y.P., MORAWSKA L., RISTOVSKI Z.D., MARSH J. Quantification of particle number and mass emission factors from combustion of Queensland trees. Environmental Science and Technology. 40, 5696, 2006.

3. KARJALAINEN P., PIRJOLA L., HEIKKILÄ J., LÄHDE T., TZAMKIOZIS T., NTZIACHRISTOS L., KESKINEN J., RÖNKKÖ T. Exhaust particles of modern gasoline vehicles: A laboratory and an on-road study. Atmospheric Environment. 97, 262, 2014.

4. KIM H., KANG K., KIM T. Measurement of particulate matter (PM2.5) and health risk assessment of cookinggenerated particles in the kitchen and living rooms of apartment houses. Sustainability. 10, 1, 2018.

5. BETHA R., SELVAM V., BLAKE D.R., BALASUBRAMANIAN R. Emission characteristics of ultrafine particles and volatile organic compounds in a commercial printing center. Journal of the Air and Waste Management Association. 61, 1093, 2011.

6. TEPE N., BAU M. Importance of nanoparticles and colloids from volcanic ash for riverine transport of trace elements to the ocean: Evidence from glacial-fed rivers after the 2010 eruption of Eyjafjallajökull Volcano, Iceland. Science of the Total Environment. 488-489, 243, 2014.

7. LAZARIDIS M., LATOS M., ALEKSANDROPOULOU V., HOV O., PAPAYANNIS A., TØRSETH K. Contribution of forest fire emissions to atmospheric pollution in Greece. Air Quality, Atmosphere and Health. 1, 143, 2008.

8. WARDOYO A.Y.P., MORAWSKA L., RISTOVSKI Z.D., JAMRISKA M., CARR S., JOHNSON G. Size distribution of particles emitted from grass fires in the Northern Territory, Australia. Atmospheric Environment. 41, 8609, 2007.

9. XU Y., BARREGARD L., NIELSEN J., A. GUDMUNDSSON, WIERZBICKA A., AXMON A., JÖNSSON B.A.G., KÅREDAL M., ALBIN M. Effects of diesel exposure on lung function and inflammation biomarkers from airway and peripheral blood of healthy volunteers in a chamber study. Particle and Fibre Toxicology. 10, 1, 2013.

10. UPADHYAY S., GANGULY K., STOEGER T., SEMMLER-BHENKE M., TAKENAKA S., KREYLING W.G., PITZ M., REITMEIR P., PETERS A., EICKELBERG O., WICHMANN H.E. Cardiovascular and inflammatory effects of intratracheally instilled ambient dust from Augsburg, Germany, in spontaneously hypertensive rats (SHRs). Particle and Fibre Toxicology. 7, $1,2010$.

11. HUK A., IZAK-NAU E., EL YAMANI N., UGGERUD H., VADSET M., ZASONSKA B., DUSCHL A., DUSINSKA
M. Impact of nanosilver on various DNA lesions and HPRT gene mutations - effects of charge and surface coating. Particle and Fibre Toxicology. 12, 1, 2015.

12. SCHNEIDER A., NEAS L.M., GRAFF D.W., HERBST M.C., CASCIO W.E., SCHMITT M.T., BUSE J.B., PETERS A., DEVLIN R.B. Association of cardiac and vascular changes with ambient $\mathrm{PM}_{2.5}$ in diabetic individuals. Particle and Fibre Toxicology. 7, 1, 2010.

13. GEISER M., ROTHEN-RUTISHAUSER B., KAPP N., SCHÜRCH S., KREYLING W., SCHULZ H., SEMMLER M., HOF V.I., HEYDER J., GEHR P. Ultrafine particles cross cellular membranes by nonphagocytic mechanisms in lungs and in cultured cells. Environmental Health Perspectives. 113, 1555, 2005.

14. SOPPA V.J., SCHINS R.P.F., HENNIG F., NIEUWENHUIJSEN M.J., HELLACK B., QUASS U., KAMINSKI H., SASSE B., SHINNAWI S., KUHLBUSCH T.A.J., HOFFMANN B. Arterial blood pressure responses to short-term exposure to fine and ultrafine particles from indoor sources - A randomized sham-controlled exposure study of healthy volunteers. Environmental Research. 158, 225, 2017.

15. JANTZEN K., MØLLER P., KAROTTKI D.G., OLSEN Y., BEKÖ G., CLAUSEN G., HERSOUG L.G., LOFT S. Exposure to ultrafine particles, intracellular production of reactive oxygen species in leukocytes and altered levels of endothelial progenitor cells. Toxicology. 359-360, 11, 2016.

16. VLAANDEREN J.J, JANSSEN N.A., HOEK G., KESKI-RAHKONEN P., BARUPAL D.K., CASSEE F.R., GOSENS I., STRAK M., STEENHOF M., LAN Q., BRUNEKREEF B., SCALBERT A., VERMEULEN R.C.H. The impact of ambient air pollution on the human blood metabolome. Environmental Research. 156, 341, 2017.

17. PRETORIUS E., MBOTWE S., BESTER J. Erythrocytes and their role as health indicator: Using structure in a patient-orientated precision medicine approach. Blood Reviews. 30, 263, 2016.

18. FAES C., CHARRIN E., CONNES P., PIALOUX V., Martin C. Chronic physical activity limits blood rheology alterations in transgenic SAD mice. American Journal of Hematology. 90, E32, 2015.

19. BELCHER J.D, MAHASETH H., WELCH T.E., OTTERBEIN L.E., HEBBEL R.P., VERCELLOTTI G.M. Heme oxygenase-1 is a modulator of inflammation and vaso-occlusion in transgenic sickle mice. The Journal of Clinical Investigation. 116, 808, 2006.

20. CLARK M.R., MOHANDAS N., SHOHET S.B. Deformability of oxygenated irreversibly sickled cells. Journal of Clinical Investigation. 65, 189, 1980.

21. CHARRIN E., OFORI-ACQUAH S.F., NADER E., SKINNER S., CONNES P., PIALOUX V., JOLY P., MARTIN C. Inflammatory and oxidative stress phenotypes in transgenic sickle cell mice. Blood Cells, Molecules, and Diseases. 62, 13, 2016.

22. ZHANG Y., ZHANG W., WANG S., WANG C., XIE J., CHEN X., XU Y., MAO P. Detection of human erythrocytes influenced by iron deficiency anemia and thalassemia using atomic force microscopy. Micron. 43, 1287, 2012.

23. WARDOYO A.Y.P., JUSWONO U.P., NOOR J.A.E. A study of the correlation between ultrafine particle emissions in motorcycle smoke and mice erythrocyte damages. Experimental and Toxicologic Pathology. 69, 649, 2017. 
24. QUIROS D.C., YOON S., DWYER H.A., COLLINS J.F., ZHU Y., HUAI T. Measuring particulate matter emissions during parked active diesel particulate filter regeneration of heavy-duty diesel trucks. Journal of Aerosol Science. 73, 48, 2014

25. MASKEY S., CHAE H., LEE K., DAN N.P., KHOI T.T., PARK K. Morphological and elemental properties of urban aerosols among PM events and different traffic systems. Journal of Hazardous Materials. 317, 108, 2016.

26. WARDOYO A.Y.P., JUSWONO U.P., NOOR J.A.E. Measurements of $\mathrm{PM}_{2.5}$ motor emission concentrations and the lung damages from the exposure mice. in 2016 International Seminar on Sensors, Instrumentation, Measurement, and Metrology (ISSIMM). 2016.

27. OLSEN Y., KAROTTKI D.G., JENSEN D.M., BEKÖ G., KJELDSEN B.U., CLAUSEN G., HERSOUG L., HOLST G.J., WIERZBICKA A., SIGSGAARD T., LINNEBERG A., MØLLER P., LOFT S. Vascular and lung function related to ultrafine and fine particles exposure assessed by personal and indoor monitoring: a cross-sectional study. Environmental Health. 13, 1, 2014.

28. ASGHARIAN B., MILLER F.J., PRICE O., SCHROETER J.D., EINSTEIN D.R., CORLEY R.A., BENTLEY T. Modeling particle deposition in the pig respiratory tract. Journal of Aerosol Science. 99, 107, 2016.

29. FARAG M.R., ALAGAWANY M. Erythrocytes as a biological model for screening of xenobiotics toxicity. Chemico-Biological Interactions. 279, 73, 2018.

30. THOMSON E.M., WILLIAMS A., YAUK C.L., VINCENT R. Toxicogenomic analysis of susceptibility to inhaled urban particulate matter in mice with chronic lung inflammation. Particle and Fibre Toxicology. 6, 1, 2009.

31. JIMENEZ L.A., THOMPSON J., BROWN D.A., RAHMAN I., ANTONICELLI F., DUFFIN R., DROST E.M., HAY R.T., DONALDSON K., MACNEE W. Activation of NF-кB by $\mathrm{PM}_{10}$ occurs via an iron-mediated mechanism in the absence of ІкB degradation, Toxicology, and Applied Pharmacology. 166, 101, 2000.

32. GYAWALI P., RICHARDS R.S., BWITITI P.T., NWOSE E.U. Association of abnormal erythrocyte morphology with oxidative stress and inflammation in metabolic syndrome. Blood Cells, Molecules, and Diseases. 54, 360, 2015.

33. REDDY A.R.N., REDDY Y.N., KRISHNA D.R., HIMABINDU V. Multi wall carbon nanotubes induce oxidative stress and cytotoxicity in human embryonic kidney (HEK293) cells. Toxicology. 272, 11, 2010.

34. GILLESPIE P.A., KANG G.S., ELDER A., GELEIN R., CHEN L., MOREIRA A.L., KOBERSTEIN J., TCHOUWONG K., GORDON T., CHEN L.C. Pulmonary response after exposure to inhaled nickel hydroxide nanoparticles: Short and long-term studies in mice. Nanotoxicology. 4, 106, 2010.

35. PLUMMER L.E., CAROSINO C.M., BEIN K.J., ZHAO Y., WILLITS N., SMILEY-JEWELL S., WEXLER A.S., PINKERTON K.E. Pulmonary inflammatory effects of source-oriented particulate matter from California's San Joaquin Valley. Atmospheric Environment. 119, 174, 2015.
36. NEMMAR A., INUWA I.M. Diesel exhaust particles in blood trigger systemic and pulmonary morphological alterations. Toxicology Letters. 176, 20, 2008.

37. FANG Z., JIANG C., TANG J., HE M., LIN X., CHEN X., HAN L., ZHANG Z., FENG Y., GUO Y., LI H., JIANG W. A comprehensive analysis of membrane and morphology of erythrocytes from patients with glucose-6-phosphate dehydrogenase deficiency. Journal of Structural Biology. 194, 235, 2016.

38. PYRSHEV K.A., KLYMCHENKO A.S., CSÚCS G., DEMCHENKO A.P. Apoptosis, and eryptosis: Striking differences on biomembrane level. Biochimica et Biophysica Acta - Biomembranes. 1860, 1362, 2018.

39. POMPEO G., GIRASOLE M., CRICENTI A., BOUMIS G., BELLELLI A., AMICONI S. Erythrocyte death in vitro induced by starvation in the absence of $\mathrm{Ca}^{2+}$. Biochimica et Biophysica Acta. 1798, 1047, 2010.

40. PHAM C.T., KAMEDA T., TORIBA A., HAYAKAWA K. Polycyclic aromatic hydrocarbons and nitropolycyclic aromatic hydrocarbons in particulates emitted by motorcycles. Environmental Pollution. 183, 175, 2013.

41. YAN C., ZHENG M., YANG Q., ZHANG Q., QIU X., ZHANG Y., FU H., LI X., ZHU T., ZHU Y. Commuter exposure to particulate matter and particle-bound PAHs in three transportation modes in Beijing, China. Environmental Pollution. 204, 199, 2015.

42. WIERZBICKA A., NILSSON P.T., RISSLER J., SALLSTEN G., XU Y., PAGELS J.H., ALBIN M., ÖSTERBERG K., STRANDBERG B., ERIKSSON A., BOHGARD M., BERGEMALM-RYNELL K., GUDMUNDSSON A. Detailed diesel exhaust characteristics including particle surface area and lung deposited dose for better understanding of health effects in human chamber exposure studies. Atmospheric Environment. 86, 212, 2014.

43. TONGO I., OGBEIDE O., EZEMONYE L. Human health risk assessment of polycyclic aromatic hydrocarbons (PAHs) in smoked fish species from markets in Southern Nigeria. Toxicology Reports. 4, 55, 2017.

44. SARIGIANNIS D.A., KARAKITSIOS S.P., ZIKOPOULOS D., NIKOLAKI S., KERMENIDOU M. Lung cancer risk from PAHs emitted from biomass combustion. Environmental Research. 137, 147, 2015.

45. BORTEY-SAM N., IKENAKA Y., AKOTO O., NAKAYAMA S.M.M, ASANTE K.A., BAIDOO E., OBIRIKORANG C., SAENGTIENCHAI A., ISODA N., NIMAKO C., MIZUKAWA H., ISHIZUKA M. Oxidative stress and respiratory symptoms due to human exposure to polycyclic aromatic hydrocarbons (PAHs) in Kumasi, Ghana. Environmental Pollution. 228, 311, 2017.

46. LOUIS C., LIU Y., TASSEL P., PERRET P., CHAUMOND A., ANDRE M. PAH, BTEX, carbonyl compound, blackcarbon, $\mathrm{NO}_{2}$ and ultrafine particle dynamometer bench emissions for Euro 4 and Euro 5 diesel and gasoline passenger cars. Atmospheric Environment. 141, 80, 2016.

47. TSAI J., HUANG P., CHIANG H. Characteristics of volatile organic compounds from motorcycle exhaust emission during real-world driving. Atmospheric Environment. 99, 215, 2014. 
